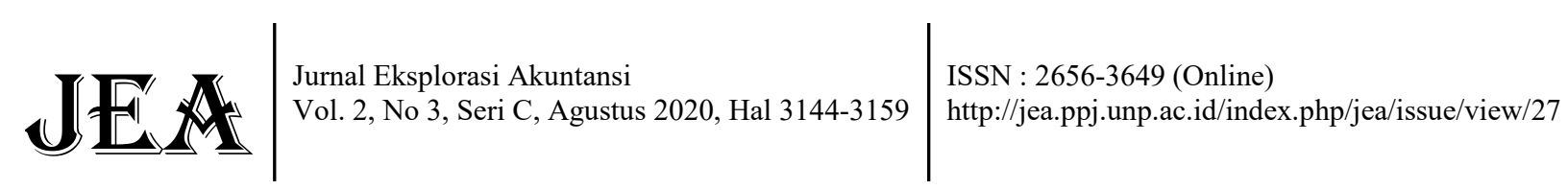

\title{
ANALISIS FLYPAPER EFFECT PADA DANA ALOKASI UMUM, DANA ALOKASI KHUSUS, DANA BAGI HASIL, DAN PENDAPATAN ASLI DAERAH TERHADAP BELANJA DAERAH PROVINSI DI INDONESIA
}

\author{
Haris Fadilah ${ }^{1}$, Nayang Helmayunita ${ }^{2}$ \\ ${ }^{1}$ Alumni Jurusan Akuntansi Fakultas Ekonomi Universitas Negeri Padang \\ ${ }^{2}$ Jurusan Akuntansi Fakultas Ekonomi Universitas Negeri Padang \\ *Korespondensi: bsrharis@gmail.com
}

Abstract: This study aims to look at the effect of the General Allocation Fund, Special Allocation Fund, Profit Sharing Funds and Regional Original Revenue towards the Regional Expenditure and to analyze the phenomenon of the flypaper effect on the Provincial Government in Indonesia. The population of this study was 34 provinces in all provinces in Indonesia. This study used the total sampling technique. The data used were the secondary data obtained from www.djpk.kemenkeu.go.id. The method used in this study was a multiple regression by using IBM SPSS 26 program. The results of this study indicated that DAU,DBH and PAD partially have a significant positive effect on the Regional Expenditure. However, the DAK variable has no effect on the Regional Expenditure. The coefficient of Balance Fund was greater than the PAD coefficient. In conclusion, there is a flypaper effect on the provincial government in Indonesia.

Keywords: DAU, DAK, DBH, PAD, BD, Flypaper Effect.

How to cite (APA $6^{\text {th }}$ style)

Fadilah. H, \& Helmayunita, N. (2020). Analisis Flypaper Effect Pada Dana Alokasi Umum, Dana Alokasi Khusus, Dana Bagi Hasil, Dan Pendapatan Asli Daerah Terhadap Belanja Daerah Provinsi Di Indonesia. Jurnal Eksplorasi Akuntansi, 2(3), Seri C, 3144-3159.

\section{PENDAHULUAN}

Otonomi daerah merupakan sebuah sistem pemerintahan desentralisasi yang dikeluarkan oleh pemerintah pusat melalui UU Nomor 32 Tahun 2004 yang sebelumnya adalah UU Nomor 22 tahun 1999. Dalam penyelenggaraan otonomi daerah, pemerintah daerah tentu memerlukan dana yang besar dalam menjalankan roda pemerintahan. Oleh sebab itu, pemerintah pusat mengeluarkan UU Nomor 33 Tahun 2004 tentang Perimbangan Keuangan Antara Pemerintah Pusat dan Pemerintah Daerah. Pada umumnya di negara-negara berkembang mendasari alokasi dana perimbangan atas aspek belanja daerah, bukan dari kemampuan daerah tersebut dalam mengumpulkan pajak lokal (Nurdini, Wiratno, \& Farida, 2015). Hal ini sesuai dengan penelitian Kuncoro (2004) yang menyatakan bahwa belanja daerah hanya mampu dibiayai sebanyak $20 \%$ oleh PAD. Akibatnya, pemerintah daerah menjadikan dana perimbangan sebagai sumber pendapatan utama dalam membiayai Belanja Daerah (Sasana, 2010). 
Belanja Daerah merupakan semua pengurangan kekayaan bersih daerah yang digunakan dalam rangka pemenuhan kewajiban daerah dalam periode anggaran bersangkutan (UU Nomor 33 tahun 2004). Belanja daerah ini akan dibiayai oleh pemasukan daerah yang terdiri dari Pendapatan Asli Daerah dan Dana Perimbangan, Apabila Dana Perimbangan direspon lebih besar oleh belanja daerah dari pada Pendapatan Asli Daerah maka fenomena ini disebut flypaper effect. Flypaper Effect merupakan suatu kondisi ketika belanja daerah lebih banyak menggunakan dana perimbangan pemerintah pusat daripada PAD (Amalia, Nor, \& Nordiansyah, 2015). Terdapat dua teori yang dapat menjelaskan fenomena flypaper effect ini, yang pertama adalah model birokratik (bureaucratic model) yang melihat dari perspektif birokrat dan yang kedua adalah ilusi fiskal (fiscal illusion model) yang melihat dari perspektif masyarakat (Kuncoro, 2007).

Pendapatan Asli Daerah merupakan pendapatan yang diterima daerah melalui pemungutan hasil pajak daerah, hasil retribusi daerah, hasil pengelolaan kekayaan daerah yang dipisahkan, dan pendapatan daerah lain-lain yang sah (Nabilah, Soelistyo, \& Kusuma, 2016).

Tabel 1

Perbandingan PAD Terhadap DAU Pemerintah Provinsi di Indonesia Tahun 2018 (Dalam Rupiah)

\begin{tabular}{ccccc}
\hline No. & Provinsi & PAD & DAU & \% PAD thdp DAU \\
\hline 1 & Sulawesi Barat & 301.499 .588 .175 & 1.025 .033 .063 .000 & $29,41 \%$ \\
\hline 2 & Maluku Utara & 358.325 .359 .307 & 1.331 .236 .347 .000 & $26,92 \%$ \\
\hline 3 & Sulawesi Tenggara & 903.949 .000 .785 & 1.575 .959 .517 .000 & $57,36 \%$ \\
\hline 4 & Maluku & 465.779 .724 .332 & 1.670 .234 .402 .000 & $27,89 \%$ \\
\hline 5 & Gorontalo & 384.435 .306 .403 & 1.006 .924 .707 .000 & $38,18 \%$ \\
\hline
\end{tabular}

Sumber : KEMENKEU (2020)

Data di atas merupakan representasi dari keadaan fiskal pemerintah provinsi yang ada di Indonesia. Berdasarkan data diatas, DAU mendominasi aspek pemasukan daerah. Perbandingan antara PAD dan DAU pada provinsi di Indonesia tahun 2018 sebesar 26,92\% sampai 57,36\%. Hal ini menjelaskan bahwa tingkat ketergantungan pemerintah daerah terhadap dana perimbangan masih tinggi untuk membiayai belanja daerah. Fenomena Flypaper effect memberikan indikasi bahwa pemerintah daerah belum mandiri dalam memenuhi kebutuhan finansial dalam menjalankan roda pemerintahan mereka sendiri. Akibatnya, tujuan dari desentralisasi fiskal untuk menciptakan kemandirian pemerintah daerah dalam aspek pendanaan Belanja Daerah belum bisa tercapai (Murniasih \& Mulyadi, 2011).

Nurdini, Wiratno, \& Farida (2015) menemukan bahwa Dana Alokasi Umum, Dana Bagi Hasil, dan Pendapatan Asli Daerah berpengaruh positif terhadap Belanja Daerah secara parsial. Namun, Dana Alokasi Khusus tidak berpengaruh positif terhadap Belanja Daerah. Pada Uji T dan Uji F ditemukan bahwa telah terjadi fenomena flypaper effect pada kabupaten/kota di Jawa Barat. Selanjutnya Sasana (2010) dan Muniarsih \& Mulyadi (2011) juga ditemukan bahwa Dana Alokasi Umum (DAU), Dana Bagi Hasil (DBH) dan Pendapatan Asli Daerah (PAD) berpengaruh positif dan signifikan. Penelitian ini juga menyimpulkan bahwa telah terjadi flypaper effect pada provinsi di Indonesia dan Pemerintah Daerah Kalimantan Timur.

Penelitian ini merupakan lanjutan dari penelitian Sasana (2010). Perbedaan penelitian ini dengan penelitian sebelumnya adalah pada penelitian ini peneliti menambahkan satu variabel independen, yaitu Dana Alokasi Khusus. Armawaddin, Rumbia, \& Afiat (2017) menyatakan bahwa Dana Alokasi Khusus berpengaruh positif dan signifikan terhadap belanja daerah secara parsial. 


\section{REVIU LITERATUR DAN HIPOTESIS}

\section{Teori Keagenan (Agency Theory)}

Menurut Jensen, Meckling, dan Eisenhardt (dalam buku Narhatyo \& Utami, 2019:73-75) menyatakan bahwa teori keagenan berfokus pada hubungan kontraktual antara prinsipal (si pemberi amanah), dengan agen (si pemegang amanah). Amanah tersebut dijalankan oleh agen untuk dan atas kepentingan prinsipal. Teori keagenan berasumsi bahwa agen dan prinsipal memiliki kepentingan masing-masing dalam menjalankan kontrak kerja. Teori keagenan memprediksi bahwa dalam hubungan prinsipal dan agen, terdapat ketimpangan informasi. Agen memiliki lebih banyak informasi daripada prinsipal (Nahartyo \& Utami, 2019). Akibatnya, terjadi permasalahan prinsipal-agen (principal-agent problem) yang berupa adverse selection (pilihan buruk) dan moral hazard (bencana moral) (Gudono, 2017).

Dalam konteks penganggaran publik, pemerintah pusat bertindak sebagai prinsipal dan pemerintah daerah sebagai agen dalam penyaluran dana perimbangan. Pemerintah pusat memberikan wewenang kepada pemerintah daerah untuk dapat mengatur daerah mereka sendiri. Akibat dari kebijakan tersebut, pemerintah pusat memberikan dana perimbangan kepada pemerintah daerah untuk membantu pemerintah daerah dalam menjalankan roda pemerintahannya sendiri. Dana perimbangan inilah yang akan dipertanggungjawabkan oleh pemerintah daerah (agen) kepada pemerintah pusat (prinsipal).

\section{Teori Peacock dan Wiseman}

Peacock dan Wisman berpendapat bahwa pemerintah cenderung meningkatkan pengeluaran melalui peningkatan penerimaan pajak. Korelasi yang positif ini mengakibatkan ketika penerimaan pajak meningkat maka pengeluaran pun akan ikut meningkat. Namun, peningkatan besaran pembayaran pajak mendapatkan respon yang tidak baik dari masyarakat (Prasetya, 2012). Teori Peacock dan Wisman mengasumsikan bahwa masyarakat memiliki tingkat toleransi dalam pembayaran pajak (Prasetya, 2012). Tingkat toleransi ini mengisyaratkan bahwa masyarakat sadar terhadap pembayaran pajak yang berfungsi membiayai pengeluaran pemerintah. Namun, tingkat toleransi ini memberikan batasan kepada pemerintah dalam menetapkan besaran pajak. Batasan dalam pemungutan pajak ini menjadi kendala bagi pemerintah dalam menaikkan pemungutan pajak secara semena-mena.

\section{Belanja Daerah (BD)}

Menurut UU Nomor 33 tahun 2004, Belanja daerah adalah semua kewajiban Daerah yang diakui sebagai pengurangan nilai kekayaan bersih dalam periode tahun anggaran yang bersangkutan. Belanja daerah digunakan dalam rangka mendanai urusan pemerintahan yang menjadi kewenangan pemerintah provinsi, baik berupa urusan wajib maupun urusan pilihan. Belanja daerah dipisahkan atas jenis, organisasi dan fungsi.

\section{Dana Alokasi Umum (DAU)}

Menurut UU Nomor 33 tahun 2004 dan PP Nomor 55 Tahun 2005, Dana Alokasi Umum adalah pendapatan transfer pemerintah daerah dari APBN yang bertujuan untuk mengurangi ketimpangan fiskal antar-Daerah dalam rangka pelaksanaan desentralisasi. Dana Alokasi Umum bersifat block grant, maksudnya adalah pemerintah daerah dapat menggunakan Dana Alokasi Umum sesuai dengan prioritas dan kebutuhan daerah guna meningkatkan pelayanan terhadap masyarakat dalam menjalankan otonomi daerah. 


\section{Dana Alokasi Khusus (DAK)}

Menurut UU Nomor 33 Tahun 2004 Dana Alokasi Khusus (DAK) adalah alokasi anggaran dari APBN kepada daerah yang telah ditentukan untuk membantu pendanaan kegiatan daerah yang bersifat khusus dan sejalan dengan prioritas nasional. DAK secara khusus membantu mendanai sarana dan prasarana daerah dalam rangka meningkatkan pelayanan publik.

\section{Dana Bagi Hasil (DBH)}

Menurut UU Nomor 33 Tahun 2004, Dana Bagi Hasil (DBH) adalah alokasi dana dari APBN untuk daerah otonom yang ditentukan berdasarkan persentase dalam rangka pelaksanaan otonomi daerah. Dana Bagi Hasil berfungsi agar tidak terjadi ketimpangan antara pemerintah pusat dengan daerah dan memberikan perhatian terhadap daerah penghasil.

\section{Pendapatan Asli Daerah (PAD)}

Pendapatan Asli Daerah merupakan dana yang diperoleh pemerintah daerah melalui pemungutan yang diatur dalam peraturan pemerintah daerah (UU Nomor 33 tahun 2004). Pendapatan daerah berfungsi untuk menunjang pemerintah daerah dalam melakukaan pendanaan terkait menjalankan roda pemerintahannya sendiri.

\section{Flypaper Effect}

Flypaper effect terjadi ketika dana perimbangan yang terdiri dari Dana Alokasi Umum, Dana Alokasi Khusus dan Dana Bagi Hasil memiliki pengaruh lebih besar terhadap Belanja Daerah daripada Pendapatan Asli Daerah (Armawaddin, Rumbia, \& Afiat, 2017). Terdapat dua teori yang dapat menjelaskan fenomena flypaper effect ini, yang pertama adalah model birokratik (bureaucratic model) yang melihat dari perspektif birokrat dan yang kedua adalah ilusi fiskal (fiscal illusion model) yang melihat dari perspektif masyarakat (Kuncoro, 2007).

\section{Pengaruh Dana Alokasi Umum Terhadap Belanja Daerah}

Hubungan antara Dana Alokasi Umum dan Belanja Daerah sangat erat. Dana Alokasi Umum merupakan salah satu elemen penting dalam memenuhi pendanaan belanja daerah. Dana Alokasi Umum yang ditransfer oleh pemerintah pusat digunakan oleh pemerintah daerah untuk membiayai belanja daerah. Belanja daerah yang menjadi sasaran dari pengalokasian Dana Alokasi Umum ini adalah belanja pegawai, belanja modal dan belanja operasional. Dalam teori agensi, pemerintah pusat bertindak sebagai prinsipal dan pemerintah daerah sebagai agen dalam penyaluran dana perimbangan.

Pemerintah pusat memberikan wewenang kepada pemerintah daerah untuk dapat mengatur daerah mereka sendiri. Akibat dari kebijakan tersebut, pemerintah pusat memberikan dana perimbangan kepada pemerintah daerah untuk membantu pemerintah daerah dalam menjalankan roda pemerintahannya sendiri. Dana perimbangan inilah yang akan dipertanggungjawabkan oleh pemerintah daerah (agen) kepada pemerintah pusat (prinsipal). Dalam penelitian Nurdini, Wiratno, \& Farida (2015) menyatakan bahwa Dana Alokasi Umum berpengaruh positif terhadap belanja daerah. Selain itu, dalam penelitian Amalia, Nor, \& Nordiansyah (2015) juga menyatakan bahwa Dana Alokasi Umum berpengaruh terhadap belanja daerah secara parsial.

$\mathbf{H}_{1}$ : Dana Alokasi Umum berpengaruh positif terhadap Belanja Daerah 


\section{Pengaruh Dana Alokasi Khusus Terhadap Belanja Daerah}

Pemerintah pusat mengalokasikan Dana Alokasi Khusus untuk memenuhi belanja daerah dalam rangka peningkatan kualitas sarana dan prasarana fisik untuk jangka panjang agar dapat mendorong percepatan pembangunan daerah. Dana Alokasi Khusus mendanai belanja daerah terkait dengan peningkatan kualitas kebutuhan fisik berupa sarana dan prasarana di bidang pendidikan, kesehatan, infrastruktur, kelautan dan perikanan, pertanian, prasarana pemerintah daerah serta lingkungan hidup (Peraturan Menteri Keuangan Nomor 128/PMK.07/2006 Tentang Penetapan Alokasi dan Pedoman Umum Pengelolaan). Armawaddin, Rumbia, \& Afiat (2017) dalam penelitiannya menyatakan bahwa Dana Alokasi Khusus secara parsial berpengaruh positif terhadap belanja daerah. Artinya, semakin besar Dana Alokasi Khusus yang diterima oleh pemerintah daerah maka akan semakin besar pula belanja daerah yang dianggarkan oleh pemerintah daerah tersebut. Disisi lain, pada penelitian Amalia, Nor, \& Nordiansyah (2015) menyatakan bahwa DAK berpengaruh negatif terhadap belanja daerah. Artinya adalah terjadi peningkatan belanja daerah ketika adanya penurunan besaran penerimaan Dana Alokasi Khusus $\mathbf{H}_{2}$ : Dana Alokasi Khusus berpengaruh positif terhadap Belanja Daerah

\section{Pengaruh Dana Bagi Hasil Terhadap Belanja Daerah}

Dana Bagi Hasil merupakan alokasi dana dari APBN untuk daerah otonom yang ditentukan berdasarkan persentase dalam rangka pelaksanaan otonomi daerah. Armawaddin, Rumbia, \& Afiat (2017) menyatakan bahwa Dana Bagi Hasil berpengaruh positif terhadap belanja daerah secara parsial. Keterkaitan Dana Bagi Hasil terhadap Belanja Daerah adalah Dana Bagi Hasil menyokong pemerintah daerah dalam mendanai Belanja Daerah. Menurut Peraturan Menteri Keuangan Republik Indonesia Nomor 19/PMK.07/2020, Dana Bagi Hasil digunakan untuk membiayai belanja daerah dalam bidang kesehatan dan untuk perbaikan gizi. Pemerintah pusat mengalokasikan Dana Bagi Hasil berdasarkan prinsip by origin. Prinsip ini mengalokasikan Dana Bagi Hasil berdasarkan daerah penghasil. Artinya, pemerintah daerah yang memiliki pendapatan yang tinggi, cenderung akan mendapatkan Dana Bagi Hasil yang tinggi pula (Kuncoro, 2007). Akibatnya, ketika pemerintah daerah mendapatkan Dana Bagi Hasil yang tinggi, maka mereka akan mampu memenuhi kebutuhan belanja daerah yang lebih besar.

$\mathbf{H}_{3}$ : Dana Bagi Hasil berpengaruh positif terhadap Belanja Daerah

\section{Pengaruh Pendapatan Asli Daerah Terhadap Belanja Daerah}

Pendapatan Asli Daerah merupakan sumber pendanaan mandiri yang didapatkan oleh daerah melalui pemungutan kepada masyarakat dan sesuai dengan perundang-undangan yang berlaku. Menurut teori yang dikemukakan oleh Peacock dan Wesman (1961), Pemerintah daerah memiliki perilaku untuk cenderung menaikkan belanja daerah melalui peningkatan tarif pajak. Peningkatan tarif pajak ini mendapat respon yang tidak baik dari masyarakat. Teori ini menyiratkan adanya korelasi positif antara pendapatan daerah dan belanja daerah.

Hal ini sesuai dengan penelitian Mulyadi \& Muniarsih (2011) yang menyatakan bahwa Pendapatan Asli Daerah berpengaruh positif terhadap belanja daerah. Pendapatan Asli Daerah merupakan indikator untuk menilai apakah pemerintah daerah telah mandiri secara finansial dalam memenuhi kebutuhan belanja daerah (Armawaddin, Rumbia, \& Afiat. 2017). Hal ini dilihat dari seberapa besar porsi Pendapatan Asli Daerah dalam memenuhi kebutuhan belanja daerah. Apabila Pendapatan Asli Daerah memberikan porsi yang lebih besar daripada Dana Perimbangan, maka pemerintah daerah dapat dikatakan mandiri secara finansial.

$\mathbf{H}_{4}$ : Pendapatan Asli Daerah berpengaruh positif terhadap Belanja Daerah 
Pengaruh Dana Alokasi Umum, Dana Alokasi Khusus, dan Dana Bagi Hasil secara simultan Dibandingkan pengaruh Pendapatan Asli Daerah terhadap Belanja Daerah secara parsial.

Perbandingan pengaruh antara DAU, DAK dan DBH secara simultan dan PAD secara parsial terhadap Belanja Daerah berguna untuk mengetahui fenomena flypaper effect pada suatu pemerintah daerah. Menurut Mello dan Barenstrein (2001) ada dua hal yang mengindikasikan terjadinya flypaper effect, (1) nilai koefisien PAD lebih kecil daripada DAU, dan Nilai kedua koefisien tersebut signifikan; (2) Dari hasil analisis ditemukan bahwa PAD tidak berpengaruh signifikan terhadap belanja daerah.

Flypaper effect terjadi ketika dana perimbangan yang terdiri dari Dana Alokasi Umum, Dana Alokasi Khusus dan Dana Bagi Hasil memiliki pengaruh lebih besar terhadap Belanja Daerah daripada Pendapatan Asli Daerah (Armawaddin, Rumbia, \& Afiat, 2017). Fenomena Flypaper effect memberikan indikasi bahwa pemerintah daerah belum mandiri dalam memenuhi kebutuhan finansial dalam menjalankan roda pemerintahan mereka sendiri. Hal ini sesuai dengan hasil penelitian dari Kuncoro (2004) yang menemukan bahwa Pendapatan Asli Daerah hanya mampu memenuhi kebutuhan belanja daerah paling besar 20\% dari total belanja daerah.

H5: Dana Alokasi Umum, Dana Alokasi Khusus, dan Dana Bagi Hasil secara simultan lebih berpengaruh terhadap Belanja Daerah daripada pengaruh Pendapatan Asli Daerah terhadap Belanja Daerah secara parsial.

\section{METODE PENELITIAN}

\section{Sampel dan Jenis Penelitian}

Penelitian ini menggunakan pendekatan deskriptif kuantitatif. Penelitian deskriptif kuantitatif menjelaskan bagaimana fenomena yang terjadi dimasyarakat saling berhubungan satu sama lain melalui statistik deskriptif. Penelitian ini mempunyai populasi berupa seluruh provinsi di Indonesia yang berjumlah 34 provinsi. Penelitian ini menggunakan teknik total sampling, sampel pada penelitian ini terdiri dari 102 data. Namun setelah dilakukan peninjauan kembali terhadap data, terdapat 11 data yan tergolong kedalam data outlier. Berikut ini sampel yang digunakan dalam penelitian :

Tabel 2

Prosedur Penentuan Data

\begin{tabular}{llc}
\hline & \multicolumn{1}{c}{ Keterangan } & Jumlah \\
\hline $\begin{array}{l}\text { 1. Laporan Realisasi Anggaran Pemerintah Provinsi di Indonesia } \\
\text { tahun 2016-2018 }\end{array}$ & 102 \\
\hline 2. Data Outlier & Jumlah data yang digunakan & 12 \\
\hline \multicolumn{2}{c}{} \\
\hline
\end{tabular}

\section{Jenis, Sumber dan Teknik Pengumpulan Data}

Data yang digunakan dalam penelitian ini adalah data dokumentasi dan data skunder yang didapat dari website Direktorat Jendral Perimbangan Keuangan dengan teknik dokumentasi.

\section{Variabel Penelitian dan Pengukuran}

Penelitian ini menggunakan Belanja Daerah sebagai variabel dependen (Y). Belanja Daerah merupakan segala pengurangan nilai kekayaan bersih daerah akibat dari pembayaran kewajiban 
pemerintah. Belanja Daerah diukur melalui rekapitulasi belanja operasi, belanja modal dan belanja tak terduga pada Laporan Realisasi Anggaran Pemerintah Provinsi bersangkutan.

Penelitian ini menggunakan variabel Dana Alokasi Umum, Dana Alokasi Khusus, Dana Bagi Hasil dan Pendapatan Asli Daerah sebagai variabel independen (X). Dana Alokasi Umum diukur berdasarkan rekapitulasi Alokasi Dasar dan Celah Fiskal. Pemerintah Pusat mengalokasikan DAK melalui kalkulasi indeks atas dasar kriteria umum, kriteria khusus dan kriteria teknis. Dana Bagi Hasil diukur melalui rekapitulasi akun Dana Bagi Hasil Pajak dan Dana Bagi Hasil Non-Pajak. Pendapatan Asli Daerah diukur melalui rekapitulasi Total pajak daerah, total retribusi daerah, total hasil pengelolaan kekayaan daerah yang dipisahkan dan lainlain pendapatan yang sah. Semua angka yang dibutuhkan untuk penelitian telah tertera dalam akun Dana Alokasi Umum, Dana Alokasi Khusus, Dana Bagi Hasil, Pendapatan Asli Daerah dan Belanja Daerah pada Laporan Realisasi Anggaran.

\section{Metode Analisis Data}

Penelitian ini menggunakan analisis regresi berganda untuk melakukan semua pengujian hipotesis. Pengolahan data dalam penelitian ini menggunakan rumus statistik pada program $I B M$ SPSS 26 dengan model regresi:

$$
Y=\alpha+\beta_{1} X_{1}+\beta_{2} X_{2}+\beta_{3} X_{3}+\beta_{4} X_{4}+e
$$

\section{HASIL DAN PEMBAHASAN Analisis Deskriptif}

\begin{tabular}{lcrrrr}
\multicolumn{7}{c}{ Tabel 3 } \\
\multicolumn{7}{c}{ Statistik Deskriptif } \\
& \multicolumn{2}{c}{ Descriptive Statistics } \\
\hline & N & Minimum & Maximum & Mean & Std. Deviation \\
\hline Belanja & 90 & 1595895168226 & 13832848610135 & 5491147410241.72 & 3188301629909.526 \\
\hline DAU & 90 & 80402179000 & 2629224545000 & 1395182800941.76 & 473832811277.217 \\
\hline DAK & 90 & 76384932000 & 3912060867549 & 1019254582234.73 & 770882452874.864 \\
\hline DBH & 90 & 0 & 2991231124961 & 451294955952.66 & 586861706762.676 \\
\hline PAD & 90 & 277686440288 & 6329138234646 & 1950851780427.11 & 1537867490425.837 \\
\hline $\begin{array}{l}\text { Valid N } \\
\text { (listwise }\end{array}$ & 90 & & & & \\
) & & & & \\
Sumber: Data hasil olahan peneliti menggunakan IBM SPSS 26 (2020)
\end{tabular}

Berdasarkan Tabel 3 dapat diketahui gambaran dari setiap variabel pada penelitian ini. Pada variabel Belanja Daerah, nilai minimum sebesar 1595895168226, nilai maksimum sebesar 13832848610135, nilai mean sebesar 5491147410241.72, nilai standard deviasi sebesar 3188301629909.526. Pada variabel DAU, nilai minimum sebesar 80402179000, nilai maksimum sebesar 2629224545000, nilai mean sebesar 1395182800941.76, nilai standard deviasi sebesar 473832811277.217. Pada variabel DAK, nilai minimum sebesar 76384932000, nilai maksimum sebesar 3912060867549, nilai mean sebesar 1019254582234.73, nilai standard deviasi sebesar 770882452874.864. Pada variabel $\mathrm{DBH}$, nilai minimum sebesar 0, nilai maksimum sebesar 2991231124961, nilai mean sebesar 451294955952.66, nilai standard deviasi sebesar 586861706762.676. Pada variabel PAD, nilai minimum sebesar 277686440288, nilai maksimum 
sebesar 6329138234646, nilai mean sebesar 1950851780427.11, nilai standard deviasi sebesar 1537867490425.837 .

Uji Asumsi Klasik

Uji Normalitas

Tabel 4

Uji Normalitas KS-Smirnov

One-Sample Kolmogorov-Smirnov Test

\begin{tabular}{llr}
\hline $\mathrm{N}$ & & Unstandardized Residual \\
\hline Normal Parameters & & 89 \\
\hline Most Extreme Differences & Mean & .0000000 \\
\cline { 2 - 3 } & Std. Deviation & .12031076 \\
\cline { 2 - 3 } & Absolute & .139 \\
\cline { 2 - 3 } & Positive & .139 \\
\cline { 2 - 3 } & Negative & -.071 \\
\hline Test Statistic & .139 \\
\hline Asymp. Sig. (2-tailed) & $.000^{c}$ \\
\hline a. Test distribution is Normal. & \\
b. Calculated from data. & \\
c. Lilliefors Significance Correction. &
\end{tabular}

\section{Uji Multikolinearitas}

Tabel 5

Uji Multikolinearitas

\begin{tabular}{|c|c|c|c|c|c|c|c|c|}
\hline Model & & Unstandardizeo & Coefficients & $\begin{array}{c}\text { Standardized } \\
\text { Coefficients } \\
\text { Beta }\end{array}$ & $t$ & Sig. & $\begin{array}{l}\text { Collinearity } \\
\text { Statistics } \\
\text { Tolerance }\end{array}$ & VIF \\
\hline$\overline{1}$ & (Constant) & -2497405184406.910 & 660123165438.340 & & -3.783 & 0.000 & & \\
\hline & DAU & 4.001 & 0.488 & 0.595 & 8.193 & 0.000 & 0.617 & 1.622 \\
\hline & DAK & -0.607 & 0.452 & -0.147 & -1.342 & 0.183 & 0.272 & 3.679 \\
\hline & DBH & 1.680 & 0.376 & 0.309 & 4.467 & 0.000 & 0.678 & 1.476 \\
\hline & PAD & 1.162 & 0.221 & 0.560 & 5.253 & 0.000 & 0.286 & 3.502 \\
\hline
\end{tabular}

Sumber: Data hasil olahan peneliti menggunakan IBM SPSS 26 (2020)

\section{Uji Heterokedastisitas}

Tabel 6

Uji Heterokedastisitas

Coefficients $^{a}$

\begin{tabular}{|c|c|c|c|c|c|c|}
\hline \multirow[b]{2}{*}{ Model } & & \multicolumn{2}{|c|}{ Unstandardized Coefficients } & $\begin{array}{l}\text { Standardized } \\
\text { Coefficients }\end{array}$ & \multirow[b]{2}{*}{$\mathrm{t}$} & \multirow[b]{2}{*}{ Sig. } \\
\hline & & $\mathrm{B}$ & Std. Error & Beta & & \\
\hline$\overline{1}$ & (Constant) & $2.697 \mathrm{E}-13$ & .000 & & 1.211 & .229 \\
\hline & $\mathrm{DAU} \times 1$ & .324 & 287 & .597 & 1.130 & .261 \\
\hline & DAK_X2 & -.132 & .251 & -3.189 & -.525 & .600 \\
\hline & DBH_X3 & .006 & .073 & .384 & .078 & .938 \\
\hline & PAD X4 & .022 & .103 & 2.154 & .217 & .828 \\
\hline
\end{tabular}

a. Dependent Variable: ABS

Sumber: Data hasil olahan peneliti menggunakan IBM SPSS 26 (2020) 


\section{Uji Autokorelasi}

Berdasarkan hasil uji normalitas, dapat dilihat bahwa nilai signifikansinya lebih kecil dari 0,05 yaitu, $0,000<0,05$. Artinya, data pada penelitian ini belum terdistribusi normal. Namun, pada penelitian dengan set data yang besar, yakni jumlah data yang lebih dari 30, asumsi normalitas menjadi tidak terlalu penting (Gujarati, 2006). Berdasarkan hasil uji multikolinearitas, nilai $V I F<10$ dan nilai tolerance $>0,1$. Sehingga dapat disimpulkan tidak terjadi gejala multikolinearitas pada data penelitian. Berdasarkan hasil uji glejser, nilai signifikansi pada variabel independen $>0,05$. Sehingga dapat disimpulkan data penelitian tidak mengalami heterokedastisitas. Berdasarkan hasil uji Durbin-Watson, dU $<\mathrm{dW}<4$-dU $(1.7508<1.812<$ 2.2492 ) maka dapat disimpulkan bahwa tidak terjadi autokorelasi antar variabel independen pada penelitian ini, sehingga model regresi layak digunakan.

Tabel 7

Uji Autokorelasi

Model Summary

\begin{tabular}{|c|c|c|c|c|c|}
\hline & & & del summars & & \\
\hline Model & $\mathrm{R}$ & R Square & $\begin{array}{l}\text { Adjusted R } \\
\text { Square }\end{array}$ & $\begin{array}{l}\text { Std. Error of the } \\
\text { Estimate }\end{array}$ & Durbin-Watson \\
\hline 1 & $.837^{a}$ & .701 & .686 & .23378 & 1.812 \\
\hline
\end{tabular}

Sumber: Data hasil olahan peneliti menggunakan IBM SPSS 26 (2020)

\section{Uji Hipotesis}

Regresi Linear Berganda

\section{Tabel 8}

Uji Regresi Linear Berganda

\begin{tabular}{|c|c|c|c|c|c|c|c|c|}
\hline \multirow[b]{3}{*}{ Model } & \multicolumn{8}{|c|}{ Coefficients } \\
\hline & & Unstandardizec & d Coefficients & $\begin{array}{l}\text { Standardized } \\
\text { Coefficients }\end{array}$ & $\mathrm{t}$ & Sig. & $\begin{array}{c}\text { Collinearity } \\
\text { Statistics }\end{array}$ & \\
\hline & & B & Std. Error & Beta & & & Tolerance & VIF \\
\hline$\overline{1}$ & (Constant) & -2497405184406.910 & 660123165438.340 & & -3.783 & 0.000 & & \\
\hline & DAU & 4.001 & 0.488 & 0.595 & 8.193 & 0.000 & 0.617 & 1.622 \\
\hline & DAK & -0.607 & 0.452 & -0.147 & -1.342 & 0.183 & 0.272 & 3.679 \\
\hline & DBH & 1.680 & 0.376 & 0.309 & 4.467 & 0.000 & 0.678 & 1.476 \\
\hline & PAD & 1.162 & 0.221 & 0.560 & 5.253 & 0.000 & 0.286 & 3.502 \\
\hline
\end{tabular}

a. Dependent Variable: Belanja

Sumber: Data hasil olahan peneliti menggunakan IBM SPSS 26 (2020)

Berdasarkan Tabel 8, diketahui nilai t sebesar 8.193 dan nilai koefisien regresi sebesar 4.001 dengan nilai sig. 0.000. Hal ini berarti Dana Alokasi Umum berpengaruh positif dan signifikan terhadap Belanja Daerah karena nilai sig. $<\alpha(0.05)$, yaitu $0.00<0.05$. Berdasarkan hasil uji $\mathrm{t}$ dapat disimpulkan bahwa hipotesis pertama yang menyatakan Dana Alokasi Umum berpengaruh positif terhadap Belanja Daerah, diterima.

Selanjutnya, untuk pengujian hipotesis kedua diketahui nilai t sebesar -1.342 dan nilai koefisien regresi sebesar -0.607 dengan nilai sig. 0.183. Hal ini berarti Dana Alokasi Khusus tidak berpengaruh terhadap Belanja Daerah karena nilai sig. $>\alpha(0.05)$, yaitu $0.183>0.05$ Berdasarkan hasil uji $\mathrm{t}$ dapat disimpulkan bahwa hipotesis kedua yang menyatakan Dana Alokasi Khusus berpengaruh positif terhadap Belanja Daerah, ditolak. 
Pada pengujian hipotesis ketiga, diketahui nilai t sebesar 4.467 dan nilai koefisien regresi sebesar 1.680 dengan nilai sig. 0.000. Hal ini berarti Dana Bagi Hasil berpengaruh positif dan signifikan terhadap Belanja Daerah karena nilai sig. $<\alpha(0.05)$, yaitu $0.00<0.05$. Berdasarkan hasil uji $\mathrm{t}$ dapat disimpulkan bahwa hipotesis ketiga yang menyatakan Dana Bagi Hasil berpengaruh positif terhadap Belanja Daerah, diterima.

Selanjutnya, pada pengujian hipotesis keempat diketahui nilai t sebesar 5.253 dan nilai koefisien regresi sebesar 1.162 dengan nilai sig. 0.000. Hal ini berarti Pendapatan Asli Daerah berpengaruh positif dan signifikan terhadap Belanja Daerah karena nilai sig. $<\alpha(0.05)$, yaitu $0.00<0.05$. Berdasarkan hasil uji $\mathrm{t}$ dapat disimpulkan bahwa hipotesis keempat yang menyatakan Pendapatan Asli Daerah berpengaruh positif terhadap Belanja Daerah, diterima.

\section{Uji F dan Koefisien Determinasi}

\begin{tabular}{|c|c|c|c|c|c|c|}
\hline \multicolumn{7}{|c|}{$\begin{array}{c}\text { Tabel } 9 \\
\text { Uji F } \\
\text { ANOVA }^{a}\end{array}$} \\
\hline Model & & Sum of Squares & $\mathrm{df}$ & Mean Square & $\mathrm{F}$ & Sig. \\
\hline \multirow{3}{*}{1} & Regression & $\begin{array}{r}5737760201142 \\
9970000000000 \\
0.000\end{array}$ & 3 & $\begin{array}{r}1912586733714 \\
3324000000000 \\
0.000\end{array}$ & 49.703 & $.000^{\mathrm{b}}$ \\
\hline & Residual & $\begin{array}{r}3309327680979 \\
5306000000000 \\
0.000\end{array}$ & 86 & $\begin{array}{r}3848055442999 \\
454300000000 . \\
000\end{array}$ & & \\
\hline & Total & $\begin{array}{r}9047087882122 \\
5280000000000 \\
0.000\end{array}$ & 89 & & & \\
\hline
\end{tabular}

a. Dependent Variable: Belanja

b. Predictors: (Constant), DBH, DAK, DAU

Sumber: Data hasil olahan peneliti menggunakan IBM SPSS 26 (2020)

Tabel 10

Uji Koefisien Determinasi DBH, DAK, DAU

Model Summary

\begin{tabular}{|c|c|c|c|c|}
\hline Model & $\mathrm{R}$ & R Square & $\begin{array}{l}\text { Adjusted R } \\
\text { Square }\end{array}$ & $\begin{array}{l}\text { Std. Error of the } \\
\text { Estimate }\end{array}$ \\
\hline 1 & $.796^{\mathrm{a}}$ & .634 & .621 & 1961646105442.940 \\
\hline
\end{tabular}

Sumber: Data hasil olahan peneliti menggunakan IBM SPSS 26 (2020)

\section{Tabel 11}

\section{Uji Koefisien Determinasi PAD}

Model Summary

\begin{tabular}{|c|c|c|c|c|}
\hline \multicolumn{5}{|c|}{ Adiusted $R$} \\
\hline Model & $\mathrm{R}$ & R Square & $\begin{array}{l}\text { Adjusted R } \\
\text { Square }\end{array}$ & $\begin{array}{l}\text { Std. Error of the } \\
\text { Estimate }\end{array}$ \\
\hline 1 & $.660^{\mathrm{a}}$ & .435 & .429 & 2409805114388.867 \\
\hline
\end{tabular}

Sumber: Data hasil olahan peneliti menggunakan IBM SPSS 26 (2020) 


\section{Tabel 12}

Perbandingan Uji F (DAU, DAK, dan DBH) dengan Uji t (PAD) terhadap Belanja Daerah

\begin{tabular}{|l|c|c|}
\hline Variabel & Uji F & Adjusted R Square \\
\cline { 1 - 1 } DAU & \multirow{2}{*}{49.703} & 0.621 \\
\cline { 1 - 1 } DAK & & 0.429 \\
\hline DBH & & 0 \\
\hline
\end{tabular}

Berdasarkan hasil uji $\mathrm{F}$ diketahui nilai $\mathrm{F}_{\text {hitung }}$ untuk pengaruh DAU, DAK dan DBH secara simultan terhadap BD senilai 49.703 dan nilai $F_{\text {tabel }}$ sebesar 2.48. Hal ini berarti DAU, DAK dan DBH berpengaruh positif dan signifikan secara simultan terhadap Belanja Daerah karena nilai $\mathrm{F}_{\text {hitung }}>\mathrm{F}_{\text {tabel, }}$ yaitu $49.703>2.48$. Berdasarkan Tabel 10 diketahui nilai Adjusted $R$ Square pengaruh DAU, DAK dan DBH secara simultan terhadap BD senilai 0.621. Maknanya, DAU, DAK dan DBH berpengaruh secara simultan terhadap BD sebesar 62.1\%. Sementara itu, Berdasarkan Tabel 11 diketahui nilai Adjusted $R$ Square pengaruh PAD secara parsial terhadap BD senilai 0.429. Maknanya, PAD berpengaruh secara parsial terhadap BD sebesar 42.9\%.

Berdasarkan perbandingan pada Tabel 12, pengaruh DAU, DAK dan DBH secara simultan terhadap BD lebih besar daripada pengaruh PAD secara parsial terhadap BD, yakni $0.621>0.429$. Maka dapat disimpulkan bahwa hipotesis kelima yang menyatakan Dana Alokasi Umum, Dana Alokasi Khusus, dan Dana Bagi Hasil secara simultan lebih berpengaruh terhadap Belanja Daerah daripada pengaruh Pendapatan Asli Daerah terhadap Belanja Daerah secara parsial, diterima. Hal ini menunjukkan bahwa terjadi fenomena flypaper effect pada DAU, DAK, $\mathrm{DBH}$, dan PAD terhadap BD Provinsi di Indonesia.

\section{Tabel 13}

Ringkasan Hasil Penelitian

\begin{tabular}{|c|l|c|c|}
\hline Hipotesis & \multicolumn{1}{|c|}{ Hipotesis } & Signifikansi & Hasil Uji Hipotesis \\
\hline $\mathrm{H}_{1}$ & $\begin{array}{l}\text { Dana Alokasi Umum } \\
\text { berpengaruh positif terhadap } \\
\text { Belanja Daerah }\end{array}$ & $\begin{array}{c}\text { Positif dan } \\
\text { signifikan }\end{array}$ & Diterima \\
\hline $\mathrm{H}_{2}$ & $\begin{array}{l}\text { Dana Alokasi Khusus } \\
\text { berpengaruh positif terhadap } \\
\text { Belanja Daerah }\end{array}$ & $\begin{array}{c}\text { Negatif dan tidak } \\
\text { signifikan }\end{array}$ & Ditolak \\
\hline $\mathrm{H}_{3}$ & $\begin{array}{l}\text { Dana Bagi Hasil berpengaruh } \\
\text { positif terhadap Belanja Daerah }\end{array}$ & $\begin{array}{l}\text { Positif dan } \\
\text { signifikan }\end{array}$ & Diterima \\
\hline $\mathrm{H}_{4}$ & $\begin{array}{l}\text { Pendapatan Asli Daerah } \\
\text { berpengaruh positif terhadap } \\
\text { Belanja Daerah }\end{array}$ & $\begin{array}{l}\text { Positif dan } \\
\text { signifikan }\end{array}$ & Diterima \\
\hline $\mathrm{H}_{5}$ & $\begin{array}{l}\text { Dana Alokasi Umum, Dana } \\
\text { Alokasi Khusus, dan Dana Bagi } \\
\text { Hasil secara simultan lebih } \\
\text { berpengaruh terhadap Belanja } \\
\text { Daerah daripada pengaruh } \\
\text { Pendapatan Asli Daerah } \\
\text { terhadap Belanja Daerah secara } \\
\text { parsial. }\end{array}$ & $\begin{array}{c}\text { Positif dan } \\
\text { signifikan }\end{array}$ & Diterima \\
\hline
\end{tabular}




\section{PEMBAHASAN}

\section{Pengaruh Dana Alokasi Umum terhadap Belanja Daerah}

Hipotesis pertama pada penelitian ini menyatakan bahwa Dana Alokasi Umum berpengaruh positif terhadap Belanja Daerah. Besaran alokasi DAU ditentukan berdasarkan formula dari akumulasi Alokasi dasar dan celah fiskal. Alokasi Dasar dilihat dari besaran realisasi gaji Pegawai Negeri Sipil pada tahun sebelumnya yang terdiri dari gaji pokok dan tunjungantunjangan yang melekat sesuai dengan regulasi yang berlaku. Sedangkan Celah Fiskal merupakan selisih dari pengurangan kebutuhan fiskal dan kapasitas fiskal.

Berdasarkan hasil uji t pada penelitian ini, ditemukan bahwa $\mathrm{H}_{1}$ diterima karena nilai sig. sebesar 0.000, sig. $<\alpha(0.005)$. Artinya, Dana Alokasi Umum berpengaruh positif signifikan terhadap belanja daerah. Besaran peningkatan DAU berbanding lurus dengan besaran peningkatan Belanja Daerah, semakin meningkat DAU, maka Belanja Daerah akan semakin mengikat pula.

Hasil penelitian ini sejalan dengan penelitian Nurdini, Wiratno, \& Farida (2015) yang membuktikan bahwa apabila besaran alokasi Dana Alokasi Umum meningkat, maka besaran alokasi Belanja Daerah akan ikut meningkat. Selain itu, Sasana (2010) juga memperoleh hasil bahwa apabila terjadi kenaikan pada DAU, maka Belanja Daerah akan mengalami peningkatan pula. Ketika terjadi peningkatan pada DAU sebesar 1 juta rupiah, maka Belanja Daerah akan ikut mengalami peningkatan sebesar 1.51 juta rupiah.

\section{Pengaruh Dana Alokasi Khusus Terhadap Belanja Daerah}

Hipotesis kedua pada penelitian ini menyatakan bahwa Dana Alokasi Khusus berpengaruh positif terhadap Belanja Daerah. Berdasarkan hasil uji t pada penelitian ini, ditemukan bahwa $\mathrm{H}_{2}$ ditolak karena nilai sig. sebesar 0.183, sig. $>\alpha(0.005)$. Artinya, Dana Alokasi Khusus tidak berpengaruh terhadap Belanja Daerah. Hal ini sesuai dengan karakteristik DAK yang bersifat khusus, maksudnya adalah pemerintah pusat mengalokasikan DAK hanya untuk keperluan khusus. Pemerintah pusat tidak mengalokasikan DAK untuk keperluan belanja rutin pada pemerintah daerah.

Selain itu, regulasi terkait pengaturan Dana Alokasi Khusus tidak serinci regulasi terkait pengaturan DAU dan DBH. Dalam UU Nomor 33 tahun 2004 hanya menyebutkan bahwa setiap tahun besaran DAK akan ditentukan dalam APBN. DAK terkesan bersifat residual karena tidak adanya ketentuan yang menyatakan terkait jumlah, proporsi dan persentase DAK dalam APBN. Hal ini menyebabkan DAK bersifat fleksibel sebagai komponen dana perimbangan (Usman, Mawardi, Poesoro, Suryahadi, \& Sampford, 2008). Fleksibelitas dari DAK akan menyebabkan pemerintah daerah tidak bisa mendapatan kepastian secara dini terkait besaran DAK yang akan dialokasikan. Akibatnya, efektifitas dan efisiensi terkait penggunaan DAK tidak maksimal.

Hasil penelitian ini sejalan dengan penelitian Nurdini, Wiratno, \& Farida (2015) yang menyimpulkan bahwa DAK tidak berpengaruh terhadap belanja daerah kabupaten/kota di Jawa Barat. Namun, penelitian ini tidak sejalan dengan penelitian yang dilakukan oleh Armawaddin, Rumbia, \& Afiat (2017) yang membuktikan bahwa pengaruh Dana Alokasi Khusus terhadap Belanja Daerah pada Kabupaten/Kota di Sulawesi adalah signifikan.

\section{Pengaruh Dana Bagi Hasil Terhadap Belanja Daerah}

Hipotesis ketiga pada penelitian ini menyatakan bahwa Dana Bagi Hasil berpengaruh positif terhadap Belanja Daerah. Pemerintah pusat mengalokasikan Dana Bagi Hasil berdasarkan prinsip by origin. Prinsip ini mengalokasikan Dana Bagi Hasil berdasarkan daerah penghasil. 
Artinya, pemerintah daerah yang memiliki pendapatan yang tinggi, cenderung akan mendapatkan Dana Bagi Hasil yang tinggi pula.

Berdasarkan hasil uji t pada penelitian ini, ditemukan bahwa $\mathrm{H}_{3}$ diterima karena nilai sig. sebesar 0.000, sig. $<\alpha(0.005)$. Artinya, Dana Bagi Hasil berpengaruh positif signifikan terhadap Belanja Daerah. Besaran peningkatan DBH berbanding lurus dengan besaran peningkatan Belanja Daerah, semakin meningkat DBH, maka Belanja Daerah akan semakin mengikat pula. Hasil penelitian ini sejalan dengan penelitian Nurdini, Wiratno, \& Farida (2015) yang membuktikan bahwa Dana Bagi Hasil berpengaruh positif dan signifikan terhadap Belanja Daerah. Selain itu Armawaddin, Rumbia, \& Afiat (2017) juga memperoleh hasil bahwa Dana Bagi Hasil mempengaruhi perubahan Belanja Daerah secara positif dan signifikan.

\section{Pengaruh Pendapatan Asli Daerah Terhadap Belanja Daerah}

Hipotesis Keempat pada penelitian ini menyatakan bahwa Pendapatan Asli Daerah berpengaruh positif terhadap Belanja Daerah. Pendapatan Asli Daerah merupakan dana yang diperoleh pemerintah daerah melalui pemungutan yang diatur dalam peraturan pemerintah daerah. Pemungutan yang dimaksud adalah berupa pajak daerah, retribusi daerah, hasil pengelolaan kekayaan daerah yang dipisahkan dan lain-lain pendapatan yang sah.

Berdasarkan hasil uji t pada penelitian ini, ditemukan bahwa $\mathrm{H}_{4}$ diterima karena nilai sig. sebesar 0.000, sig. $<\alpha(0.005)$. Artinya, Pendapatan Asli Daerah berpengaruh positif signifikan terhadap Belanja Daerah. Besaran peningkatan PAD berbanding lurus dengan besaran peningkatan Belanja Daerah, semakin meningkat PAD, maka Belanja Daerah akan semakin mengikat pula. Hasil penelitian ini sejalan dengan penelitian Astutik \& Kuntara, (2017) yang menyatakan bahwa Pendapatan Asli Daerah berpengaruh positif terhadap Belanja Daerah. Artinya, ketika pemerintah daerah dapat meningkatkan realisasi PAD, maka besaran alokasi Belanja Daerah akan ikut meningkat. Selain itu, Rasyid (2019) juga meneliti tentang pengaruh DAU, DAK, DBH, dan PAD terhadap Belanja Daerah pada Kabuppaten/Kota Provinsi Sulawesi Tengah dan memperoleh hasil bahwa PAD mempunyai pengaruh yang signifikan terhadap perubahan Belanja Daerah.

Pengaruh DAU, DAK, DBH Terhadap BD Dibandingkan Dengan Pengaruh PAD Terhadap BD Dan Analisis Flypaper Effect Pada Pemerintah Provinsi Di Indonesia

Hipotesis kelima pada penelitian ini menyatakan bahwa Dana Alokasi Umum, Dana Alokasi Khusus, dan Dana Bagi Hasil secara simultan lebih berpengaruh terhadap Belanja Daerah daripada pengaruh Pendapatan Asli Daerah terhadap Belanja Daerah secara parsial. Berdasarkan Hasil Uji F diketahui nilai $F_{\text {hitung }}$ untuk pengaruh DAU, DAK dan DBH secara simultan terhadap BD senilai 49.703 dan nilai $F_{\text {tabel }}$ sebesar 2.48. Hal ini berarti DAU, DAK dan DBH berpengaruh positif dan signifikan secara simultan terhadap Belanja Daerah karena nilai $F_{\text {hitung }}>F_{\text {tabel, }}$ yaitu $49.703>2.48$.

Selain itu, nilai Adjusted $R$ Square pengaruh DAU, DAK dan DBH secara simultan terhadap BD senilai 0.621. Maknanya, DAU, DAK dan DBH berpengaruh secara simultan terhadap BD sebesar 62.1\%. Sedangkan, nilai Adjusted $R$ Square pengaruh PAD secara parsial terhadap BD senilai 0.429. Maknanya, PAD berpengaruh secara parsial terhadap BD sebesar 42.9\%. Pengaruh DAU, DBH dan DAK secara simultan lebih besar daripada pengaruh PAD secara parsial terhadap Belanja Daerah. Dari hasil perbandingan diatas, dapat disimpulkan bahwa pemenuhan pembiayaan Belanja Daerah lebih didominasi oleh dana yang berasal dari alokasi 
DAU, DAK dan DBH. Hal ini menunjukkan bahwa telah terjadi fenomena flypaper effect pada pada DAU, DAK, DBH dan PAD pada Provinsi di Indonesia.

Fenomena flypaper effect menandakan bahwa tingkat ketergantungan pemerintah daerah terhadap dana perimbangan masih tinggi untuk membiayai Belanja Daerah. Fenomena flypaper effect memberikan indikasi bahwa pemerintah daerah belum mandiri dalam memenuhi kebutuhan finansial dalam menjalankan roda pemerintahan mereka sendiri. Akibatnya, tujuan dari desentralisasi fiskal untuk menciptakan kemandirian pemerintah daerah dalam aspek pendanaan Belanja Daerah belum bisa tercapai (Murniasih \& Mulyadi, 2011).

Hasil penelitian ini sejalan dengan penelitian Sasana (2010) yang menyatakan bahwa Besaran alokasi Dana Alokasi Umum lebih mendominasi dalam kebijakan Belanja Daerah daripada Pendapatan Asli Daerah. Belanja Daerah lebih merespon Dana Alokasi Umum daripada Belanja Daerah. Selain itu Suryani (2018) juga memperoleh hasil bahwa telah terjadi fenomena flypaper effect pada Dana Alokasi Umum dan Pendapatan Asli Daerah terhadap Belanja Daerah Pemerintah Kabupaten/Kota Provinsi Jawa Timur.

\section{SIMPULAN, KETERBATASAN DAN SARAN \\ Kesimpulan}

Berdasarkan hasil temuan penelitian dan pengujian hipotesis yang telah diajukan sebelumnya, maka dapat disimpulkan :

1. Hipotesis pertama diterima, yakni Dana Alokasi Umum berpengaruh positif terhadap Belanja Daerah. Artinya semakin tinggi penerimaan Dana Alokasi Umum, maka besaran Belanja Daerah akan semakin meningkat.

2. Hipotesis kedua ditolak, dimana Dana Alokasi Khusus tidak berpengaruh terhadap Belanja Daerah. Artinya Dana Alokasi Khusus bukanlah faktor yang mempengaruhi perubahan Belanja Daerah pada penelitian ini.

3. Hipotesis ketiga diterima, yakni Dana Bagi Hasil berpengaruh positif terhadap Belanja Daerah. Artinya semakin tinggi penerimaan Dana Bagi Hasil, maka besaran Belanja Daerah akan semakin meningkat.

4. Hipotesis keempat diterima, yakni Pendapatan Asli Daerah berpengaruh positif terhadap Belanja Daerah. Artinya semakin tinggi penerimaan Pendapatan Asli Daerah, maka besaran Belanja Daerah akan semakin meningkat.

5. Hipotesis kelima diterima, yakni terjadi fenomena flypaper effect pada Belanja Daerah Pemerintah Provinsi Di Indonesia

\section{Keterbatasan}

Peneliti telah berusaha untuk mendesain penelitian ini sebaik mungkin, namun masih terdapat keterbatasan dalam menyelesaikan penelitian ini. Keterbatasan yang masih perlu diperbaiki untuk penelitian selanjutnya adalah:

1. Penelitian ini hanya menggunakan data sekunder yang didapatkan dari website www.djpk.kemenkeu.go.id sehingga tidak melibatkan faktor-faktor variabel cross-secion seperti perilaku Pemerintah Daerah dan perubahan regulasi.

2. Penelitian ini hanya menggunakan pengamatan dengan rentang waktu selama tiga tahun yaitu 2016-2018 


\section{Saran}

Berdasarkan kesimpulan dan keterbatasan yang telah peneliti jabarkan sebelumnya, maka saran yang dapat peneliti berikan adalah sebagai berikut:

1. Diharapkan kepada pemerintah daerah agar menggali potensi daerahnya seperti intensifikasi penerimaan pajak daerah dan meminimalisir penggunaan dana perimbangan sehingga terciptanya daerah otonom yang mandiri.

2. Diharapkan kepada peneliti selanjutnya untuk memasukkan variabel cross section seperti perilaku pemerintah daerah dan perubahan regulasi.

\section{DAFTAR PUSTAKA}

AMALIA, W. R., NOR, W., \& NORDIANSYAH, M. (2015). FLYPAPER EFFECT PADA PENDAPATAN ASLI DAERAH (PAD), DANA ALOKASI UMUM (DAU), DANA ALOKASI KHUSUS (DAK) TERHADAP BELANJA DAERAH PADA PEMERINTAH KABUPATEN/KOTA DI PROVINSI KALIMANTAN SELATAN (2009-2013). JURNAL AKUNTANSI DAN BISNIS, 1-12.

ARMAWADDIN, M., RUMBIA, W. A., \& AFIAT, M. N. (2017). ANALISIS FLYPAPER EFFECT BELANJA DAERAH KABUPATEN/KOTA DI SULAWESI. JURNAL EKONOMI DAN PEMBANGUNAN INDONESIA, 77-91.

ASTUTIK, E. N., \& KUNTARA, A. D. (2017). FLYPAPER EFFECT AND FACTORS AFFECTING REGIONAL GOVERNMENT'S EXPENDITURE AT DISTRICTS OF YOGYAKARTA SPECIAL REGION PROVINCE 2008 - 2014. ASIAN ACADEMIC ACCOUNTING ASSOCIATION 18TH ANNUAL CONFERENCE. BALI: ASIAN ACADEMIC ACCOUNTING ASSOCIATION.

GUDONO. (2017). TEORI ORGANISASI. YOGYAKARTA: PENERBIT ANDI.

GUJARATI, D. N. (2006). DASAR-DASAR EKONOMETRIKA JILID 1. JAKARTA: PENERBIT ERLANGGA.

KEMENKEU, D. (2020, APRIL 10). PORTAL DATA. RETRIEVED FROM DJPK.KEMENKEU.GO.ID:

HTTP://WWW.DJPK.KEMENKEU.GO.ID/PORTAL/DATA/APBD

KUNCORO, H. (2004). PENGARUH TRANSFER ANTAR PEMERINTAH PADA KINERJA fISKAL PEMERINTAH DAERAH KOTA DAN KABUPATEN DI INDONESIA. ECONOMIC JOURNAL OF EMERGING MARKETS [JURNAL EKONOMI PEMBANGUNAN: KAJIAN EKONOMI NEGARA BERKEMBANG], 47-63.

KUNCORO, H. (2007). FENOMENA FLYPAPER EFFECT PADA KINERJA KEUANGAN PEMERINTAH DAERAH KOTA DAN KABUPATEN DI INDONESIA. SIMPOSIUM NASIONAL AKUNTANSI X, 1-29.

MURNIASIH, E., \& MULYADI, M. S. (2011). PENGARUH TRANSFER PEMERINTAH PUSAT TERHADAP PERILAKU FISKAL PEMERINTAH DAERAH DI PROVINSI KALIMANTAN TIMUR. JURNAL EKONOMI DAN PEMBANGUNAN INDONESIA, 56-71.

NABILAH, A. N., SOELISTYO, A., \& KUSUMA, H. (2016). ANALISIS FLYPAPER EFFECT PAD DAN DAU TERHADAP BELANJA DAERAH DI PROVINSI KALIMANTAN TIMUR TAHUN 2010-2014. JURNAL EKONOMI PEMBANGUNAN.

NAHARTYO, E., \& UTAMI, I. (2019). PANDUAN PRAKTIS RISET EKSPERIMEN. JAKARTA BARAT: PENERBIT INDEKS JAKARTA. 
NURDINI, R., WIRATNO, A., \& FARIDA, Y. N. (2015). ANALISIS FLYPAPER EFFECT PADA DANA ALOKASI UMUM (DAU), DANA ALOKASI KHUSUS (DAK), DANA BAGI HASIL (DBH) DAN PENDAPATAN ASLI DAERAH (PAD) TERHADAP BELANJA DAERAH (BD) KABUPATEN/KOTA DI JAWA BARAT. JURNAL AKUNTANSI DAN KEUANGAN, 80-94.

PERATURAN MENTERI KEUANGAN NOMOR 128/PMK.07/2006 TENTANG PENETAPAN ALOKASI DAN PEDOMAN UMUM PENGELOLAAN.

PMK RI NOMOR 19/PMK.07/2020 TENTANG PENYALURAN DAN PENGGUNAAN DANA BAGI HASIL, DANA ALOKASI UMUM, DAN DANA INSENTIF DAERAH TAHUN ANGGARAN 2020 DALAM RANGKA PENANNGULANGAN CORONA VIRUS DISEASE 2019 (COVID-19).

PP NOMOR 55 TAHUN 2005 TENTANG DANA PERIMBANGAN.

PRASETYA, F. (2012). MODUL EKONOMI PUBLIK BAGIAN V: TEORI PENGELUARAN PEMERINTAH . MALANG: FAKULTAS EKONOMI DAN BISNIS UNIVERSITAS BRAWIJAYA.

RASYID, M. (2019). PENGARUH DANA ALOKASI UMUM, DANA ALOKASI KHUSUS, DANA BAGI HASIL DAN PENDAPATAN ASLI DAERAH TERHADAP BELANJA DAERAH KABUPATEN/KOTA PROVINSI SULAWESI TENGAH. E JURNAL KATALOGIS, 204-2016.

SASANA, H. (2010). FLYPAPER EFFECT PADA DANA ALOKASI UMUM, DANA BAGI HASIL, DAN PENDAPATAN ASLI DAERAH TERHADAP BELANJA DAERAH PADA PROVINSI DI INDONESIA. EKO-REGIONAL, 61-66.

SURYANI, A. I. (2018). LYPAPER EFFECT PADA PENDAPATAN ASLI DAERAH (PAD) DAN DANA ALOKASI UMUM (DAU) TERHADAP BELANJA DAERAH (STUDI PADA PEMERINTAHAN KABUPATEN/KOTA DI PROVINSI JAWA TIMUR, JAWA TENGAH DAN JAWA BARAT PERIODE 2011-2013). JOURNAL OF ACCOUNTING SCIENCE, 165-179.

USMAN, S., MAWARDI, M. S., POESORO, A., SURYAHADI, A., \& SAMPFORD, C. (2008). MEKANISME DAN PENGGUNAAN DANA ALOKASI KHUSUS (DAK). LEMBAGA PENELITIAN SMERU.

UU NOMOR 32 TAHIN 2004 TENTANG PEMERINTAHAN DAERAH.

UU NOMOR 33 TAHUN 2004 TENTANG PERIMBANGAN KEUANGAN ANTARA PEMERINTAH PUSAT DAN PEMERINTAH DAERAH. 